\title{
2
}

\section{New directions in theory-building}

\section{Treaty reform in perspective}

\section{The SEA and beyond}

In the mid-1980s, the whole scene became dominated by claims of a 'neofunctionalist comeback' - modified in nature, yet easily discernible in scope. Processes of negative integration primarily at the market level were linked with the development of a wide range of policies covering almost all spheres of regional co-operation. Neofunctionalist 'spillovers' were envisaged for the transformation of a 'Business Europe' to a 'People's Europe': the functions of the larger management system seemed to have produced not only new expectations but also new pressures for further integration. But the institutional evolution of the Community was lagging behind its (re)emerging neofunctionalist ambitions. The SEA did not represent a qualitative leap towards a 'self-regulating pluralist society' at the regional level, or even towards high levels of political autonomy on the part of supranational institutions.

Although it needs to be pointed out that the Delors Commission did try to develop an independent strategy for managing the ' 1992 process' and to exploit its enormous publicity - a project supported at the time by even the most 'reluctant' Europeans including British Prime Minister Thatcher - the states once again found ways of resisting any substantive movement towards a profound transformation of the Community system: supranationalism championed in areas where the states wanted to see progress, such as the implementation of the single market programme (and even here there was to be a target date rather than a legally binding date for its completion). In those areas where national interests were, or appeared to be, at stake, such as European Political Co-operation (EPC) that was merely codified in a legal text, intergovernmentalism effectively prevailed as the dominant mode of decision-taking. Moreover, no subsequent alteration of the locus of sovereignty emerged as a result of 
the coming into force of the SEA in July 1987, although it did pave the way for higher levels of power-sharing in the Community system. An equally important line of criticism directed against resurgent neofunctionalist aspirations came from a number of scholars who stressed the fact that the theory did not take into account the wider international environment within which Community change was to flourish. ${ }^{2}$

So why did neofunctionalism, which had been obsolescent for some twenty years, emerge once again as the leading theory of European integration? A possible answer is that the SEA was hailed by many observers at the time as opening up new horizons for positive integration. Neofunctionalism was in fact the only theory that could place, if not justify, these claims in a dynamic, macropolitical perspective. After all, the analytical validity of the theory had been linked from the outset with the development of the Community political system and now there was a widespread sense of a renewed dynamism in the integration process. In particular, there was a feeling that the single market plan would not allow for any critical drawbacks. Instead, it was seen as constituting the 'motor' of integration, the long-needed integrative project that would accelerate the pace of the regional process by mobilising political elites, trade unions and the wider business community towards a commonly shared - and, crucially, feasible objective. At the same time, there were mounting expectations that the dynamics of economic integration would soon spill over into the institutional sphere. Although new sources of possible pressure became manifest in a wide range of policy domains, neofunctionalist analysis concentrated on the stimulus rather than the outcome of the envisaged spillovers; that is, on the integrative dynamic rather than on the consequence of the newly generated impetus.

For instance, it was expected that increased trade and, albeit to a lesser extent, financial interdependencies would lead, in a somewhat deterministic fashion, towards a full-blown monetary union on the grounds that positive movement at one level of integration would set up problems that could only be resolved at another level. But there was no immediate link, nor was there any automatic mechanism to that end. On the contrary, much had to rely upon the convergence of interests among the dominant governing elites, which also had to take into account what such a move would entail for the sovereignty of their respective polities. The crucial question missed by 'new neofunctionalism' was how far can Community competences be extended beyond the traditional state level without raising the sensitive issue of national sovereignty? Even in the case of the SEA, for all the new dynamism and innovative strategy shown by the Delors Presidency, despite the existing political consensus among the national governing elites, and despite even the positive mobilisation of non-governmental actors around the ' 1992 project', the level of European integration cannot be said to have been significantly advanced.

However, it is equally difficult to assume that the member state governments decided to refocus, as Haas might have it, their loyalties, activities and political expectations on a new regional centre, for no such 'centre' ever came into being 
with the SEA. Moreover, neither the inherent technical characteristics of the vision of a 'Europe without frontiers', nor the utilitarian calculus of 'the cost of non-Europe', nor even the introduction of QMV in the Council (which was mainly aimed at speeding up European legislation in areas related to the completion of the single market) and of a new co-operation procedure upgrading (under certain conditions) the legislative role of the EP, can be said to correspond to what neofunctionalists originally had in mind: the regional centralisation of authoritative decision-making driven by the expansive logic of integration and, eventually, the emergence of a new European 'political community'.

\section{Reflections on the TEU}

This section considers the state of theorising European integration in the 1990s in relation to the political and constitutional physiognomy of the Maastricht Treaty. Such an inquiry is of particular theoretical interest as none of the previously dominant paradigms of regional integration in Europe provide an overall hermeneutic pattern. Rather, different theoretical accounts intermesh with enormous complexity as to the outcome of the twin Intergovernmental Conferences of 1990/91. A possible explanation is that from a phase of integration in the mid-1980s, when expected 'spillovers' monopolised the interest of the academic community, we moved into a situation where a process of 'overspill' became manifest: ${ }^{3}$ the scope of integration - that is, the range of things that states decide to do together - had by then seriously expanded, whereas its level had become all the more difficult to dissociate from the control of state executives. Indeed, the component states were equally anxious to preserve the integrity of their respective polities, and hence to continue their existence as distinct sovereign entities and even reinforce their own autonomy, rather than be drawn into a system of uncontrolled institutional centralisation followed by advanced schemes of federalism and, as some may have it, regional state-building.

Art. A TEU states that 'The Union shall be founded on the European Communities, supplemented by the policies and forms of cooperation established in this Treaty'. Accordingly, the Union provides for a general umbrella under which the pre-established Communities continue to exist as separate legal entities. The EC is the more advanced component of a three-pillar structure complemented by the Common Foreign and Security Policy (CFSP) and Co-operation in Justice and Home Affairs (JHA). The latter pillars, by establishing two additional 'pluralist' arenas, reveal the limits of majority voting in still sensitive policy areas. The locus decidendi of the new competencies 'pooled' to the central institutions in these sectors rests firmly in the hands of the Council, the limited consultative role of the Commission and the EP notwithstanding. As Taylor put it: 'The whole was to be consolidated into a single package of activities linked in systems of common management. ${ }^{4}$ Owing to the cautiously designated stages of joint decision-making, the procedures operating in these pillars resemble an exercise in transnational regime formation: a co-operative venture based upon a commonly agreed set of principles, norms, rules and procedures, elaborate enough 
to promote a relatively high degree of horizontal interaction among the states, and elastic enough to be wholly consistent with the pursuit of a wide range of segmental interests in EU affairs. ${ }^{5}$ As Bulmer and Scott put it: 'the two new pillars of the Union constitute an extension of the terrain of inter-state cooperation ... a strengthening of the kind of intergovernmental arrangements which exacerbate the democratic deficit.' ${ }^{3}$ This point is further supported by the perpetuation of a complex 'comitology' system which evades proper parliamentary control, national or European; the issue of extending the EP's coresponsibility over the Community's compulsory expenditure (agriculture); the question of a uniform procedure for European elections; and a wide range of issues relating to the openness, clarity and transparency of EU decision-making.

According to Art. E TEU, the four main institutions of the Union shall exercise their powers 'under the conditions and for the purposes provided for' by the provisions of the Treaty, while Art. N TEU renders all parts of the Treaty subject to the same revision rules. And since the TEU rests on two different sets of legal mechanisms - the Community Method and intergovernmental co-operation the extent to which it has provided for a 'single institutional framework' is far from self-evident. However, Demaret recognises that 'the dividing line between the two types of mechanisms and between their respective fields of application is, in several instances, less than clear-cut.' ${ }^{7}$ But even despite these reservations, the legal maze of the TEU has raised more questions than it originally sought to address, proving to be 'a source of controversy'. As Wallace put it: 'the terms of Maastricht ... can be interpreted as easily as making efforts to set a ceiling on, even a roll back of, the forces of supranationalism as they can be seen as crossing a new threshold on the route towards a European transnational polity. ${ }^{9}$ It is thus conceivable that the Union does not possess a legal personality of its own. Rather, 'it must be considered a new international organization sui generis and thus as a subject of international law. ${ }^{10}$ If by the term 'international organisation' we mean 'a formal, continuous structure established by agreement between members ... from two or more sovereign states with the aim of pursuing the common, interests of membership, ${ }^{11}$ then challenging this view is no easy task. Suffice it to stress that the confusion surrounding the 'constitutionality' of the TEU is supportive of the fact that for many scholars the question whether the Union has moved closer to a federal type of polity remains largely unanswered.

What is also remarkable in the central arrangements brought about by the TEU is the insistence of sovereignty-conscious states to protect their own cultural, political and constitutional features; a point clearly made in Art. F(1) TEU: 'The Union shall respect the national identities of the Member States, whose systems of government are founded on the principles of democracy.' This is indicative of the need to sustain a pluralistic form of society at the regional level, implying that any challenge to constituent identities would be legally and practically unacceptable. The search for unity through an 'uneasy compromise' between federalism and confederalism implies a series of interstate concessions to meet the challenges of joint decision-making, without losing sight of the 
growing quest for national autonomous action. Both points seem to substantiate the view that, owing to the premium it places on preserving (territorial) segmental autonomy within a sensibly arranged 'union', the TEU is characterised by a unique blend of consensual mechanisms for accommodating segmental diversity within a nascent, yet fragile, political unity. Joining together diverse entities in a regional union that respects their individual integrity, the constitutional structure of the Union challenges the organic theory of the polity, without relying entirely on the properties of 'segmented differentiation'. From this stems its greatest merit as a system of mutual governance, but also its strongest concern: to provide equality of status to its members while allowing for a less rigid understanding of sovereign statehood. In fact, the TEU offers an advanced conception of the practice of political co-determination. This has been achieved so far by applying a mixed system of consensus and majority government, consistent with what Forsyth had earlier defined as 'unanimity at the base, majority voting in the superstructure..12

The political fragility of the new arrangements was clearly manifested not only during the negotiations leading up to the signing of the TEU in February 1992, but also during its arduous course of ratification and the subsequent 'optouts' secured by the more sceptical members as a quid pro quo for consenting to the Union project. Against the background of an ever more cynical electorate, any residual touch of optimism from the mid-1980s seemed to have evaporated by the conclusion of the ratification process in October 1993. Although the TEU finally managed to survive the new tides of Euroscepticism, a new 'democratic disjunction' became manifest between the wishes of national leaders and popular political sentiments. ${ }^{13}$ As in past treaty revisions, the TEU reflected in a most tenacious way the ongoing tussle between those defending the rights of states (as sovereign units) and those projecting an independent legitimacy for the Union (as an composite polity). In Neunreither's words: 'It is a text for insiders, not only in being difficult to read and to digest, but even more because of its paternalistic approach - everything is done for the people, not very much by the people. ${ }^{14}$ Thus the lesson to be learned from the Maastricht process is that unless there is a sufficient area of consensus at the elite level, no viable outcome(s) can exist. This accords with what most students of integration had implicitly assumed: over the 1990s, the weight of the evidence is that the extension of the scope and level of European integration has exploited a crucial property of consensual politics: the capacity to reconcile the challenges of institutional innovation with the need for systemic continuity. The conclusion to be drawn is that 'the burden of proof' lies more on federalism than on intergovernmentalism as a method of organising both the internal and external affairs of the general system. This view is further supported by the rather moderate, and certainly unimaginative, reform packages agreed in Amsterdam and Nice in June 1997 and December 2000, respectively, which will be examined later in this study.

Having examined some crucial aspects of the TEU, it is time to consider in greater detail some of the stimulating theoretical attempts to (re)conceptualise, 
largely from a political systemic perspective, the emerging properties and functions of the regional system. Of particular interest here are liberal intergovernmentalism, the fusion thesis, new institutionalism, multilevel governance, the international state thesis, the concepts of condominio and consortio, the examination of the Union's state-like properties in comparison with other forms of state, the confederal consociation thesis, as well as new normative perspectives on EU theorising, such as neo-republicanism and constructivism.

\section{New theoretical approaches}

\section{Liberal intergovernmentalism}

The approach developed by Moravcsik in the early 1990s aimed at widening the spectrum of scholarly debate about the evolution of the EU system, its internal decision-making procedures and, more importantly, the relationship between domestic politics and international co-operation - the latter is achieved mainly by using Putnam's analogy of the two-level games. ${ }^{15}$ Liberal intergovernmentalism, in attempting to restore the superiority of state-centric approaches to the study of regional integration, purports to explain, on the one hand, the interaction between states and international organisations and, on the other, the relationship between national preference-formation, coalitional behaviour and interstate bargaining. What is distinctive in this approach is that it offers a range of intellectual opportunities for moving beyond 'unicausal theorising', by integrating three important subdisciplines of general international relations theory: regime analysis, negotiation theory and intergovernmentalism. The wider theoretical concern revolves around an understanding of the dynamic interplay between a liberal interpretation of national preference-formation, the rationality of actors pursuing their interests at the central level and the distinct nature of intergovernmental bargaining within the Community system.

The welcoming aspect of this analysis is that it links the domestic political orders and economic agendas of states to joint decision-making, as well as to coalition-formation in the Council. Moravcsik argues that Community institutions, which are generally taken as highly reactive agents operating within a 'passive structure', strengthen the power of national governments in two important respects: 'they increase the efficiency of interstate bargaining', often by acting as 'facilitators of positive-sum governing', and they 'strengthen the autonomy of national political leaders vis-à-vis particularistic societal groups within their domestic polity ${ }^{16}$ The point being made in the latter case is that state executives mediate between domestic interests and Community action: integration outcomes are shaped by the relative bargaining power of national governments and by the distribution of preferences among them. The Community's transaction cost-reducing function, its highly institutionalised policy co-ordination environment and the institutional delegation (pooling of sovereignty) that take place at the larger level (mainly through the application of majority rule) 
are important factors towards a viable negotiating order: 'a successful intergovernmental regime designed to manage economic interdependence through negotiated policy co-ordination. ${ }^{17}$ In brief, despite its many critics (who are particularly sceptical of the theory's working assumptions on state rationality and its tendency to downplay the impact of decision rules and institutional preferences), Moravcsik's 'new intergovernmentalism' represents a attempt to bridge the gap between neofunctionalist pre-theorising and 'substantive' theorising, by proposing a challenging research agenda, which places the emphasis on the primacy of interstate bargaining in determining the pace and range of the regional arrangements.

\section{The fusion thesis}

Wessels' analysis on the subject projects a dynamic macropolitical view of the integrative process. ${ }^{18}$ The argument he puts forward is that European integration is characterised by an 'ever closer fusion' of 'public instruments from several levels linked with the respective Europeanisation of national actors and institutions. ${ }^{19}$ Wessels stresses the development and importance of institutionalised patterns of joint problem-solving between national and European governance structures for the fulfilment of public needs. This makes the larger system part of the evolution of West European statehood itself. In Wessels' words: 'it is a crucial factor and dynamic engine of the fundamental changes in the statehood of western Europe'; thus attributing to the Union a much more complex role than that of merely 'rescuing the nation state' in the Milwardian sense. ${ }^{20}$ Conceptually, the term 'fusion' is taken to mean something more than merely a 'horizontal pooling of sovereignties' as understood by mainstream realist state-centric analyses. Rather, it bears a strong resemblance to the functioning of the German political system of 'interlocking' federalism or Politikverflechtung, which in turn refers to a continuous process of negotiation between state and federal agents in the determination of national policy. In fact, this particular form of interlocking authority structures becomes part of Wessels' explanatory variables for the patterns of political systemic growth and differentiation in the Union.

Applied to the Union's composite polity, 'fusion' refers, according to Wessels, to the 'merger' of public resources located at several levels of governance, including substate structures. This, however, has as a result the blurring of responsibilities among the actors involved and, by extension, an increased difficulty in tracing the accountability of diffused policies. This kind of 'messy federalism', to borrow a phrase, is also reminiscent of the way in which politics operates in the German system, where an apparent 'accountability deficit' stems from the complexity and composite nature of national policy-making in determining which particular actor or set of actors is responsible for which decision(s). In general terms, the Union is treated as 'the logical product of fundamental choices by member governments', operating through 'package deals', without however undermining the role of central institutional actors, which remain important 'in shaping the perceptions of national actors. ${ }^{21}$ In 
short, the fusion thesis purports to explain the new challenges confronting the evolution of West European states and the way in which they, as the basic units constituting a larger polity, 'try to achieve an increased effectiveness in applying public instruments by using efficient procedures on the one hand, while maintaining a major say through broad and intensive participation on the other. ${ }^{22}$

\section{New institutionalism}

Leaving aside the apparent methodological sophistication of new institutionalism, many of its explanations rely upon a rather uncomplicated (and until recently largely unqualified) assumption that institutions make a difference in the process of organising public life: whether formal or informal in kind, institutions are not merely epiphenomena: they form a constitutive part of a fuller and for that matter more profound understanding of complex social reality. Indeed, the revival of institutional analysis as an indispensable element in conducting political science research is partly to do with an attempt to tackle new challenging questions about the changing conditions of the liberal constitutional polity and of novel processes of socioeconomic governance, and partly to do with the equally demanding task of providing better explanations about the causal impact different institutions have on specific policy outcomes, by means of influencing - i.e., systematising, structuring, constraining, etc. - the formation of actors' preferences and the pursuit of their interests. New institutionalist accounts also assert that institutions, conceived as non-neutral arenas of human governance, facilitate the exchange of information among actors, offer the possibility of informal contacts, assist the internalisation of norms, enhance the quality of communicative action, promote patterns of co-operative behaviour (often by means of shaping the behaviour of those working within their structures), and map the expectations of actors on issues of social and political change. In particular, institutions are capable not only of promoting change, but also of constraining it, as well as touching upon sensitive issues of actors' identity, rather than merely acting as neutral or passive instruments for aggregating societal interests and claims.

The arguments mounted in support of new institutionalism in the discussion of the EU political system can be summarised as follows: supranational institutions have an impact on the behaviour of national governing elites and domestic policy actors, while becoming important venues for conflict resolution; the present-day Union offers the most advanced form of regional institutionalisation based on both formal and informal mechanisms of rule-making and norm-setting; post-SEA, there is a notable re-embrace of institutional analysis, treating institutions as meaningful, autonomous actors in the European policy setting, often by means of imposing constraints on rule-based state behaviour; systemic growth in the Union has often led to a series of 'unintended consequences' regarding the influence and competence acquisition of supranational institutions at the expense of state executives which can no longer act as gatekeepers; explaining and understanding the evolution of the integrative 
system can no longer rely on an analysis of 'grand episodes' and 'history-making' decisions through formal interstate negotiations; supranational institutions limit the capacity of states to exercise effective and/or ultimate political control in either setting the integrative agenda or in determining integration outcomes; the emergence of new policy norms and regulatory practices influencing EU policy-making.

Focusing on the impact of the central institutions on integration processes, Bulmer analyses the transformation of European governance from a comparative public policy perspective, ${ }^{23}$ offering a new institutionalist account that goes beyond both purely descriptive empiricism and reductionist political analysis. In doing so, his illuminating analysis has placed EU institutions 'in a context which allows differentiation between formal political institutions, informal conventions and the norms and beliefs embedded within those institutions.' ${ }^{24}$ The underlying assumption here is that institutions matter: 'that political struggles are mediated by prevailing institutional arrangements. ${ }^{25} \mathrm{New}$ institutionalism treats institutions as instruments capable of shaping 'the pattern of political behaviour', going 'beyond the formal organs of government' to include 'standard operating procedures, so-called soft-law, norms and conventions of behaviour. ${ }^{26}$ Both the SEA and the TEU, Bulmer notes, can be understood from a historical institutionalist perspective, for they created and extended the competences of the Community and have generated changes in the conventions and norms embedded in the central institutions. ${ }^{27}$ Bulmer's analysis does not point either to a holistic or a unifocal approach, but rather complements other theoretical endeavours in their examination of EU politics and governance in the 1990s.

In general, the new institutionalist political science raises challenging research questions about the institutional dynamics of macropolitical orderbuilding; the consequences of institutional reform (through formal or informal means and procedures); the impact on constitutive norms on actual policy performance; the ways in which institutions structure the interaction between different actors, shape their choices and influence their behaviour; the relationship between continuity and change in a system of institutionalised rule; the interplay between institutional affirmation and transformation; the intrinsic and extrinsic importance of institutional settings, and so on. Having said this, however, it is still imperative to qualify further the central institutionalist tenet, namely that institutions matter. Here, a promising research agenda drawn from the domain of comparative politics has recently emerged, examining not only the question of whether or not institutions are important, but also for what, while touching upon issues of regime or system-wide performance and institutional causality. It is almost a certainty, at least for the foreseeable future, as well as a very welcoming aspect in EU theory-building, that institutional approaches to the study of European integration will grow stronger and that its students will be better equipped to deal in a more insightful and systematic manner with such intricate issues as the impact of less formalised arenas of 
governance on integration outcomes, the role of institutional values in everyday policy-making and, crucially, the normative context within which the constitutive actors and governance arrangements of the European polity operate as norm-setting forces.

\section{Multilevel governance}

In stark contrast to state-centric approaches to European integration like liberal intergovernmentalism (which generally perceive the EU system as a means of enhancing state sovereignty or autonomy), the 'multilevel governance' school aims to inform our understanding of an emerging European polity that is increasingly characterised by overlapping competences and structures of political authority. In this context, Marks, Hooghe and Blank have directed their foci to the study of the Union as a system of 'multilevel governance. ${ }^{28}$ Being critical of (realist) state-centrism, this group of scholars looks at the 'polity-creating process' that is currently emerging in Europe, leading to a situation whereby 'authority and policy-making influence are shared across multiple levels of government', and where national governments 'have lost some of their former authoritative control over individuals in their respective territories. ${ }^{29}$ The point the authors make is that 'the locus of political control has changed' - state executives do not monopolise decision-making competencies any longer - and that '[i]ndividual state sovereignty is diluted in the Union by collective decisionmaking among national governments' and by 'the increased autonomy and independent influence that $\mathrm{EU}$ institutions have come to enjoy.3.

There are indeed limits to both individual and collective state executive control: increased majoritarianism in the Council and the regression of its (once dominant) 'veto culture'; the mistrust among state executives; the role of interest group organisations and transnational actors in the actual policy process; the intensified interconnection of different political arenas, the increased complexities and specialisation of collective public policy-making (requiring detailed regulation); the co-legislative rights of the EP; the agenda-setting role of the Commission along with its substantive informational capacity and policy implementation influence; the political dynamics of the ECJ's legal activism; domestic party political competition; subnational mobilisation, national constitutional constraints on formal treaty change, and so on, are only a few factors to mention. From this school of thought, EU policy-making is characterised by mutual dependence, complementary functions and overlapping competencies. ${ }^{31}$ The Union is thus taken as a 'multilevel polity' composed of interlocked arenas for political contest, where direct links are established among actors in diverse political arenas, where political control is diffuse - often leading to 'second-best' policy outcomes, in turn resulting from Scharpf's notion of a 'joint-decision trap' or Politikverflechtungsfalle - and where 'states no longer serve as the exclusive nexus between domestic politics and international relations [or intergovernmental bargaining]',32 Although it is not claimed that supranational institutions will eventually supersede the member state executives, multilevel governance 
theorists argue that no single locus of accumulated political authority exists, or for that matter is likely to come into being, owing to the largely 'post-sovereign' character of the Union, in that authority cuts across traditional state boundaries and domains of policy action. A major difference between liberal intergovernmentalism and the multilevel governance approach is that, according to the former, governments bargain the interests of domestic actors in state-dominated arenas, while the latter acknowledges the mobilisation of domestic actors directly in the transnational arena through their involvement in multilevel policy networks, where they represent one out of many competing actors.

Multilevel governance carries at least two important meanings in relation to national sovereignty. First, there is a notion of a single, albeit pluralistic and asymmetrical, regional polity, within which sovereignty is dispersed among competing political actors which chose to bypass their central national authorities in their dealings with Brussels. The European polity thus transcends the traditional bond between territory, function and, increasingly, identity, and becomes a new venue for conflict resolution, interest articulation and the representation of claims stemming from 'smaller', diverse, but politically organised units. This perspective, which in large measure leads to a postmodern approximation of EU reality, stresses the limits of state sovereignty in advanced processes of union and the penetration of diverse social and political settings. A second meaning to national sovereignty denotes a new type of collective action that recognises the constitutional foundations of sovereignty as resting on the member state polities, but challenges the capacity and, hence, the functional autonomy of states to respond effectively to pressing socioeconomic realities. In this sense, subnational mobilisation becomes an additional vehicle for the reallocation of authoritative problem-solving capacity to constitutive entities within a polity that remains dependent in critical ways on its subsystems, but which also allows for new structures of political opportunity to emerge. This implies a dynamic understanding of governance, not so much as the political capacity to steer, but as a practical means for domestic actors to influence largescale policy-making by hitting several access points directly. To summarise the two conceptions of sovereignty: in the first case, contrary to the hierarchical order of the Westphalian sovereignty regime, there is an explicit acknowledgement of the structural transformation of the nation-state, which now becomes an integral part of a new multilevel polity of diffused public authority and governance functions. In the second case, the state retains de jure sovereignty but loses its autonomy - its capacity rather than authority to control events - in performing its tasks as the principal actor for the articulation of domestic interests, as well as in projecting its political domination of collective problem-solving.

\section{International state}

In an illuminating analysis about the 'post-ontological' stage of contemporary EU studies (the emphasis being on explanation rather than categorisation), Caporaso sheds light on the character of the European polity and the possible 
ways of conceptualising its evolving institutional structure from the theoretical perspective of different 'forms of state. ${ }^{33}$ His insightful research encourages the analyst to develop a deeper and, comparatively speaking, historically informed understanding of the Union as a 'regional international state': 'an international structure of governance based on the extrusion of certain political activities of its constituent units. ${ }^{34}$ Caporaso is also critical of the view that equates the emergence of EU authority structures, however novel or difficult to conceptualise in traditional political systemic terms, with a direct loss of national autonomy. Instead, he urges the analyst to focus on 'the ongoing structure of political authority and governance', that is, the complex interaction of economic and political relations among the member states, which are mediated by supranational institutions. ${ }^{35}$

Drawing on three stylised 'forms of state' as 'conceptually possible expressions of political authority organised at the national and transnational levels ${ }^{36}-$ the Westphalian state, the regulatory state and the postmodern state - Caporaso makes the point that each of these distinct governance structures captures a significant part of the evolving EU reality. After clarifying, however, that his analysis represents a 'comparative exploration of three metaphors rather than a test of three theories', he argues that the first ideal state form helps us to perceive regional integration as 'a re-enactment of the traditional processes of statebuilding from the seventeenth through to the twentieth centuries'; the second encourages us to think of the present-day European polity as 'a supranational state specialising in the control and management of international externalities'; and the third directs us to an understanding of the general system as a 'polymorphic structure', which is characterised by the absence of a strong institutional core, is increasingly fragmented, has no clear public sphere as compared to its domestic counterparts and where 'process and activity become more important than structure and fixed institutions. ${ }^{37}$

In general terms, Caporaso's understanding of the Union as an 'international state' is closer to the regulatory and postnational forms of polity than to the traditional Westphalian state model. Such an understanding of the EU system, while remaining historically informed, marks a shift away from vertically defined end products such as 'political community', 'federal state', 'constitutional union' and the like which, to borrow from Haas, 'foreclose real-life developmental possibilities'. Instead, Caporaso's preferred lines of investigation and resulting conceptual understanding are able to incorporate different visions and ideal-type (normative) orientations of European political order. Notwithstanding the view that statist analogies to the study of the European polity are only partly justified, and that hypothetical integration outcomes are, at best, 'mere provisional points in the future', Caporaso's international state thesis encourages contemporary integration theorists to focus more closely on 'the ongoing structure of political authority and governance', that is, the complex interaction of economic and political relations among the subunits that are mediated by the central institutions. In short, his examination contributes to a 
'post-ontological' account of the emerging European polity informed by a novel instance of social formations, interests and interactions that are embedded in an international structure of governance.

\section{Consortio and condominio}

Schmitter's examination of 'some alternative futures for the European polity' through the projection of novel forms of political organisation constitutes a welcome contribution to the debate about the evolution of the Union. ${ }^{38}$ Arguing that the latter already represents 'the most complex polity that human agency has ever devised', Schmitter rejects the idea that the end state of integration will be 'a "re-run" of the processes and policies that earlier made the nation state the predominant political institution of Europe'; instead, he claims that the Union, presently lacking a locus of clearly defined authority, a central hierarchy of public offices, a distinct sphere of competence, a fixed territory, an exclusive recognition by other polities, an overarching identity, a monopoly over legitimate coercion and a unique capacity to impose its decisions, "is well on its way [to] becoming something new' ${ }^{39}$

What might this 'new' entity be? Two possible suggestions from Schmitter, presented as ideal-types, warrant our attention. The first refers to the notion of a 'consortio', defined as 'a form of collective action . . . where national authorities of fixed number and identity agree to co-operate in the performance of functional tasks that are variable, dispersed and overlapping. ${ }^{40}$ In it, the segments retain their respective territorial identities and 'accept positions within a common hierarchy of authority, but pool their capacities to act autonomously in domains they can no longer control at their own level of aggregation.' ${ }^{41}$ Another possible, albeit less imaginative, integration outcome is the emergence of what Schmitter calls 'condominio', referring to a complex regional arrangement based on 'a variation in both the territorial and the functional constituencies.' ${ }^{42} \mathrm{He}$ explains: 'Instead of a Eurocracy accumulating organisationally distinct but politically co-ordinated tasks around a single centre, there would be multiple regional institutions acting autonomously to solve common problems and produce different public goods ... Moreover, their dispersed and overlapping domains ... could result in competitive, even conflictual, situations and would certainly seem inefficient when compared with the clear demarcations of competence and hierarchy of authority that (supposedly) characterise existing nation states. ${ }^{\prime 3}$

At present, Schmitter concludes, the idea of a condominio-type outcome, somewhat reminiscent of Haas' multivariate integration scheme termed 'asymmetrical authority overlap', emanates as the most probable trajectory of the European polity. Schmitter's analysis is not a-historical. For all the novelty of his alternative integration scenaria for the future of Europe, he offers a general conceptual justification for applying the terminology of pre-existing forms of polity to the study of contemporary Europe. In particular, he embraces the view that, in the interests of conceptual refinement and historically informed comparisons, 
one has to turn to the past to recapture a more diverse language about political units. Revisiting European history, especially its early modern phase, where the continent witnessed the emergence of 'composite states' characterised by a system of shared sovereignty, overlapping political arenas and multiple points of contention, offers scholars the opportunity to draw valuable insights and categories of analysis in order to get their bearings in a present that is in flux. Rethinking the present Union in light of past experiences of polity-building is a productive way of sparking scholarly imagination in studying processes that have also evolved through different phases, and which are reminiscent of those currently under way. More importantly, such lines of inquiry provide the cognitive resources necessary not only for the framing of intriguing hypotheses, but also for functional analogies of recent developments to be tested. At the same time, Schmitter's analysis helps integration scholarship to become familiar with an otherwise nebulous image of EU polity-building, by allowing for the transfer of assumptions and ideas from novel political formations, which can in turn offer a useful conceptual laboratory for insightful comparative investigations to be drawn.

\section{Confederal consociation}

The concept of 'confederal consociation' was first introduced in the mid-1990s, drawing on Taylor's earlier work, as a means of capturing the dialectic between fragmentation and stability in the EU polity. The point made was that the TEU gave birth to an advanced form of regional organisation, which can best be defined as a compound polity whose distinct culturally defined and politically organised units are bound together in a consensually prearranged form of 'union' for specific purposes, without losing their sense of forming collective national identities or resigning their individual sovereignty to a higher central authority. ${ }^{44}$ Confederal consociation emanates as a promising analogy in filling the existing gap between state-centric and federalist-inspired approaches to European integration, suggesting that the constituent governments have discovered new ways of strengthening their positions both regionally and internationally. Indeed, the three-pillar structure created by the TEU, similar to an ancient Greek temple, and the moderate reforms brought about by its recent revisions, help to maximise the states' influence in deciding upon matters of common concern, while allowing them to enjoy what Lijphart described earlier as 'a high degree of secure autonomy in organising their own affairs. ${ }^{45}$

Segmental autonomy, therefore, supported by an accommodative mutual veto, a proportional representation of all states to the central institutions, and an increased propensity of national leaders to rely on what Taylor called 'government by alliance ${ }^{46}$ via reversible dissensus practices in joint decision-making, highlights the determination of states to exercise managerial control over integration, even if this implies the striking of less ambitious settlements among them. Confederal consociation has an interesting analogue with a system of horizontal Kooperative Staaten, in that the collective power of component parts is 
well preserved by making progress towards further formal integration dependent on the convergence of national preferences, as in the workings of the European Council which represents the Union's 'grand coalition' forum for striking interstate compromises. This polycentric and multilogical pattern of federalism co-exists with a more favourable version of intergovernmentalism as a method of promoting unification, and is based on the premise that the defence of each separate interest coincides with the need to strike a deal in the context of an intersegmental positive-sum game. It may best be defined as a case of 'inverse federalism': a situation in which political authority tends to be diffused as much as possible to the segments and away from the central institutions of governance. ${ }^{47}$ This mode of interaction may be seen as a discernible integrative stage, where the dynamics of elite-led governance shape the forms that EU federalism is allowed or indeed prohibited from taking. In brief, territorial politics is becoming stronger in the larger system as the scope of joint decisions is being extended, thus bringing the locus decidendi of the central political system closer to the domain of state agents.

The last property of confederal consociation, that of 'controlled pluralism', highlights the elite-dominated character of EU decision-making, in that the members of the elite cartel are induced to adopting the working principles of 'joint consensual rule'. This co-operative dynamic conflicts with the 'winnertakes-all' ethos which subsists in majoritarian systems, deviating also from normative democratic theory and its insistence on 'rule by the many'. But it accords with the development of consensus politics at the leadership level, supported by a transnational political culture among the national governing elites. By dismissing an 'either/or' conception of EU politics, confederal consociation makes the point that the extension of central competences is compatible not only with the very idea of statehood itself, but also with further national state-building, subnational community-strengthening and multiple identity-holding. It also contains a suggestion both of the non-conflictual character of EU power-sharing and of the means through which the separateness of the segments, in the form of well consolidated democracies, is compatible with processes of 'institutionalised compromise'. Hence, the preservation of 'pluralism-within-unity' is conditioned by an overarching concern at the elite level for meeting the conditions of stable governance.

Finally, by emphasising elite-driven, as opposed to demos-led, integration, the model suggests that the dialectical co-existence of a plurality of forces pressing simultaneously for a more centralised or decentralised, loose or coherent, technocratic or democratic Union, passes through the capacity of states to retain ultimate control over both European constitutional choice and change. This system of consensus elite government, in which high levels of interconnectedness co-exist with segmental autonomy, approximates the type of community detected by Taylor as 'managed Gesellschaft': 'a decentralised though coordinated system of political interaction in which the segments ... are characterised by high levels of interdependence with each other, but nevertheless preserve and 
even augment their autonomy. ${ }^{38}$ What is striking in this unique interplay between co-ordinated interdependencies and diffuse political authority is that the interests of the 'territorial state' co-exist with those of the central institutions insofar as they are products of consensual inter-elite negotiations. ${ }^{49}$ This last observation, which has important and, one might argue adverse, implications for the emergence and consolidation of a European civic demos ab intra, ${ }^{50}$ brings us to the final part of our theoretical inquiry, asking an oft-raised question: where do we go from here?

\section{Constructivism}

This strand in EU theorising, heavily drawing from constructivist approaches to international relations theory, has arguably come closer to instituting a systematic 'second-order discourse' in the study of the European polity. In 1999, a special issue of the Journal of European Public Policy was devoted to the 'Social Construction of Europe', recognising the value of a normatively informed, metatheoretical research context to EU polity-building, by investigating, inter alia, the impact of constitutive norms and rules; the role of ideas and communicative action; the uses of language and deliberative processes; the interplay of routinised practices, socialisation, symbolism and institutional interaction; and the interplay between agent identity and interests. The whole exercise was meant to herald a 'constructivist turn' in EU studies, aiming 'to go beyond explaining variation [in politics and policy] within a fixed setting' and to stress 'the impact of "intersubjectivity" and "social context" on the continuing process of European integration ... [in brief, to call attention to] the constructive force of the process itself? ${ }^{51}$

The starting point of this emergent research trend is an aspect of change, in that integration has 'a transformative impact on the European state system and its constituent units', as well as a firm belief in taking the logic and methods of social science inquiry seriously and incorporate into the process of understanding social reality 'human consciousness' and 'ideational factors' with a normative as well as instrumental dimension..$^{52}$ The gist of the argument is that there exists 'a socially constructed reality' as an expression of what Ruggie calls 'collective intentionality. ${ }^{53}$ Keeping in mind that there is both a realist and an idealist component in constructivist thought, constructivism represents a social theory with a strong interdisciplinary reach, straddling the lines between the various subfields of social science research. This interdisciplinary trend is exemplified in the writings of Shaw and Wiener, whose aim is 'to track norms from "the social" to "the legal" ... [and] trace the empirically observable process of norm construction and change ... with a view to examining aspects of "European" constitutionalism [and citizenship practice]. ${ }^{54}$ Their core set of conclusions is that EU constitutional politics as 'day-to-day practices in the legal and political realm as well as the high dramas of IGCs and new Treaties' is about 'fundamental ordering principles which have a validity outwith the formal setting of the nation state', that 'norms may achieve strong structuring power ... 
[and] are created through interaction', and that ' $[t]$ he processes of norm construction and rule-following are mutually constitutive. ${ }^{55}$

The general question posed by constructivist theorists in EU studies is 'to what extent, and in which ways, a new polity is being constructed in Europe. ${ }^{56}$ The principal aim is to problematise the changing social ontologies of European polity-formation. It is on this premise that middle-range constructivist theorising becomes well suited to the study of the European polity, directing its research foci to 'the juridification and institutionalization of politics through rules and norms; the formation of identities and the construction of political communities; the role of language and discourse. ${ }^{57}$ Although it would be rather difficult, as it would be unfair, to reach an authoritative conclusion on the overall contribution of constructivism to the field, for it is both a recent and an ongoing attempt 'to enlarge the theoretical toolbox of EU studies', ${ }^{58}$ a multitude of useful analytic and epistemological insights can be drawn from an interdisciplinary constructivist research programme that places metatheoretical thinking at the centre of understanding the social ontology of the European polity, thus creating 'an arena in which ontological shifts and meta-theoretical moves can be debated'. ${ }^{59}$

Particularly with reference to issues of polity and democracy, constructivism represents a critical normative turn in integration studies, in that the means and ends of the Union's social legitimation are increasingly becoming the object of analysis. In this context, the emphasis has not been exhausted, as in other approaches, on the question which body of theory can best explain the constitutive norms and rules of European governance per se, but rather which type of theorising offers a deeper understanding of the European polity in relation to the sociopsychological conditions of European identity-building. Whether this metatheoretical approach will contribute to the emergence of a conceptual consensus about the construction of a democratic theory of European integration - a task requiring the refinement of integration theory and the development of 'transcendent perspectives' on a range of conventional dispositions that existing theories and approaches hold - is difficult to foresee. Yet, the point is clearly made in constructivist discourses that familiarity with metatheory is a two-way process: it helps to develop 'overarching theoretical perspectives' and appreciate their relevance to 'first-order theorising'.

\section{(Neo)republicanism}

In its basic conception, a res publica aims at fulfilling three fundamental ends: justice through the rule of law; the common good/public interest through a mixed and balanced constitution; and liberty (or civic freedom) through active citizenship. Overall, Omnia reliquit servare rempublicam captures the republican imagination of a virtue-centred life, defined in civic terms. It is worth noting that, even 2510 years since the founding of the Roman republic, an anniversary that passed largely unnoticed by present-day Europeans, the above features constituting the raison d'être of the res publica continue to mark their impact in the 
interminable search - scholarly and otherwise - for 'the good polity'. Recently, republican thought managed to infiltrate the disorderly universe of EU theorising, by yielding some valuable new insights into an already voluminous aquis académique on how best to conceptualise the evolving Union. Such approaches, however, have become more than simply 'trendy': new republican perspectives on the Union sought not only to revive, but also to nurture a paradigm of social and political organisation founded on a new 'civic partnership' among distinct historically constituted demoi. Indeed, republican conceptions of Europe are part of a demanding intellectual current: the search for a reliable as well as democratic theory of integration able to capture the dialectic between strengthening the viability of the component public spheres through the institutionalisation of a mixed sovereignty regime. The point being made here is that, absent a formal (or material) European constitution, and given the inchoateness - at best - of a European civic demos (and corresponding lack of an input-oriented European legitimacy), there is urgent need for a substantive restructuring of the Union's civic arenas with a view to engaging its citizens in its governance structures. This philosophy accords fully with a civic conception of the European polity that aims to assess the relationship between the Union and 'the civic'. Such normative explorations have been recently brought into focus, often by employing the language of 'second-order discourse', especially in the sphere of collective norm-orientation and political constitutionalism. Their distinctive contribution to the field is that they have given rise to a 'normative turn' in contemporary EU studies, signalling at the same time a paradigm shift from 'policy to polity', or from 'diplomacy to democracy' - or, more accurately, 'from democracies to democracy'.

Pace the view that, for all the richness of recent normative investigations, the Union will continue to be, at least for the foreseeable future, 'an ongoing social scientific puzzle', Bellamy and Castiglione have attempted to capture the Union's complexity, pluralism and hybridity - in that its political system displays a 'baffling mixture' of federal and intergovernmental properties - through a theory of 'democratic liberalism' based on 'a pre-liberal conception of constitutionalism that identified the constitution with the social composition and form of government of the polity. ${ }^{60}$ This amounts to a political system capable of dispersing power within civil society, while encouraging dialogue between the component parts of the polity. 'Instead of the constitution being a precondition for politics', Bellamy and Castiglione note, 'political debate becomes the medium through which a polity constitutes itself ${ }^{61}$ Being highly critical of any territorial and/or hierarchical distribution of power, democratic liberalism brings the constituent groups of the polity into an equilibrium with one another, aiming at dispersing power so as 'to encourage a process of controlled political conflict and deliberation [as a way of filtering and channelling preferences] ... moving them thereby to construct and pursue the public good rather than narrow sectional interests. ${ }^{62}$ The theory goes that, within this pluralist polity characterised by a differentiated social context, there can be different 
forms of representation employed for different purposes. Differentiation is crucial to the kind of political constitutionalism advocated by democratic liberals, as it links together justice, the rule of law and the democratic dispersal and division of power, while providing a balanced mix of social forces and levels of authoritative decision-making.

From a similar prism, by reviving the usage of an eighteenth-century term, MacCormick suggests that the European polity can be best defined as a 'mixed commonwealth', within which the subjects of the 'constitution' are not homogeneous, but rather represent a mixture of political agents that share in the sovereignty of the larger political entity. ${ }^{63}$ Bellamy and Castiglione explain this point well: 'The polycentric polity that is therefore emerging is a definite departure from the nation state, mainly because it implies a dissociation of the traditional elements that come with state sovereignty: a unified system of authority and representation controlling all functions of governance over a given territory. ${ }^{64}$ MacCormick's notion of a lawfully constituted European commonwealth of post-sovereign states, whose normative validity stems largely from the existence of a well-established legal order (supported by foundational norms, basic doctrines, and general principles), allows the regional polity to conduct itself as a Rechtsgemeinschaft but not as a Rechtsstaat. Within it, and absent 'a single power-structure with a single normative frame, ${ }^{65}$ or, to borrow from Lindberg and Scheingold, ${ }^{66}$ in the context of an 'ambiguous pluralist system', political authority is neither proportionately nor symmetrically vested in an overarching centre, but is rather distributed through overlapping arrangements, with the polity being characterised by various degrees of decentralisation and infinitely tiered multiple loyalties. ${ }^{67}$ Informed by an associative understanding of governance, this pluralist depiction of the European polity as an essentially heterarchical order within which sovereignty is dispersed across and between a variety of actors and public domains, and where a 'balanced constitution' emerges as the ultimate protective mechanism against the danger of domination - political, judicial, constitutional or otherwise - is fully in line with Tarrow's insightful and historically informed definition of the Union as a 'composite polity': 'a system of shared sovereignty, partial and uncertain policy autonomy between levels of governance, and patterns of contention combining territorial with substantive issues'. ${ }^{68}$ Tarrow's conceptualisation largely draws from the work of historian Wayne te Brake on the formation of 'composite states' in early modern Europe, where people 'acted in the context of overlapping, intersecting, and changing political spaces'. ${ }^{69}$

Republican theory embodies a strong normative commitment to democratic deliberation for the promotion of the public interest, as opposed to factional demands, and to the setting up of a particular kind of constitutional ordering based on the idea of 'balanced government'. Such ordering, in the form of a constitutional state, is dedicated to offering citizens 'undominanted' (or quality) choice. But it is not the latter that causes liberty. Rather, liberty is constituted by the legal institutions of the republican state. In this context, democratic 
participation is not taken as an end in itself, but rather a means of ensuring a dispensation of non-domination or non-arbitrary rule. Another republican variation on the theme of vita activa takes civic participation 'as a process of constructing politics, not merely one means among others to secure something else'. In brief, the rule of law, opposition of arbitrariness and the republican constitution are constitutive of liberty, conceived in republican terms as civic freedom. With reference now to the idea of 'balanced government', Craig argues that it was forged in two related ways: negatively, by associating the constitution of 'a proper institutional balance' with the aim of preventing tyranny; and positively, by ensuring a deliberative form of democracy, 'within which the different "constituencies" which made up civil society would be encouraged to treat their preferences not simply as givens, but rather as choices which were open to debate and alteration' ${ }^{70}$ More than that, liberty was expected to be best preserved under 'a mixed form of republican governance' through certain constitutional practices or provisions, whereby no single component part of government would be privileged over the others; such normative issues, claims Craig, are of relevance when considering the actual distribution of authority within the Union. ${ }^{71}$ Here, republicanism claims to strike a balance between participation in the European legislative process and the attainment of the general public good, by allowing for 'a stable form of political ordering for a society within which there are different interests or constituencies. ${ }^{72}$ In institutional terms, the idea of a 'balanced constitution' in the Union is reflected in the Commission's exclusive right to initiate legislation and its interaction with civil society, the EP's co-decision rights in fostering more deliberative outcomes and the relationship between the Council's indirect democratic mandate and the fact that the Union rests on a system of treaty-based rules.

But there also exist other facets of republican thinking relevant to a civic conception of Europe. Lavdas, for instance, draws on Pettit's seminal study on freedom as non-domination - as opposed to a negative conception of liberty as non-interference, or to a positive conception of it as self-mastery - to argue that the larger polity may develop in the future the democratic functions of institutionalised public deliberation (and a corresponding concern with active or participatory citizenship), which are necessary, but not sufficient, conditions for a more 'democentric' process of union. ${ }^{73}$ Given the absence of an engaging European demos, a republican mode of governance emanates as an appropriate means of disentangling 'the issue of participation in an emerging polity from the cultural and emotional dimensions of citizenship as pre-existing affinity and a confirmation of belonging. ${ }^{74}$ The point here is that 'some elements of the real and symbolic res publica, may sustain a degree of political motivation vis-à-vis the Union and its relevance for peoples' lives while also allowing for other and more intense forms of motivation and involvement at other levels of participation' ${ }^{75}$ But given the apparent lack of organic unity among Europe's constituent demoi, the republican challenge is one of institutionalising respect for difference and group rights (in line with the dictates of multiculturalism), while sustaining a 
shared sense of the public good. This is more likely to be achieved through Pettit's third concept of freedom (as non-domination), in that it 'enables a view which aims to combine the recognition of the significance of the pluralism of cultural possibilities for meaningful choice and a framework based on a minimal set of shared political values. ${ }^{76}$ From these neo-republican expositions, one could imagine a European res publica, within which a multitude of commitments may generate higher levels of civic engagement, while enhancing the possibilities of meaningful choices on the part of the composite demos through the institutionalisation of a deliberative, rather than aggregative, model of governance.

\section{Concluding note}

Every theoretical journey has its own rewards. These may stem either from a plurality of intellectual formulations exploring the nature of complex political phenomena, or indeed from wider methodological and/or epistemological concerns. The theoretical examination of the Union qua polity or system of governance, and of European integration processes more generally, is no exception. On the contrary, it is through the conceptual and analytical lenses offered by a rich corpus of regional integration theory that one may develop a more profound understanding of the structural properties, behavioural characteristics and operational dynamics of what is frequently referred to as 'the emerging European polity'. The term 'polity' constitutes an appropriate point of reference for two significant reasons: first, it is ideologically free from the narrow and often analytically vulnerable insights offered by classical (realist) state-centric approaches to European integration; second, it is capable of avoiding the equally biased interpretations of a supranationalist conception of the larger system.

On the other hand, that no present theoretical account of recent developments in the Union claims to represent the nucleus from which a new 'grand theory' of regional integration might emerge, that is, one with widely applicable comparative insights, is almost self-evident. Likewise, none of the prevailing interpretations of the Union in general, and of EU polity-building in particular, is capable of predicting with a degree of confidence the future evolution of the regional system. On the contrary, prediction is altogether treated as a risky exercise and has thus been avoided by most contemporary analysts, Schmitter's imaginative research on alternative and often unprecedented integration outcomes notwithstanding. But there is something inherently fascinating and rewarding in undertaking such risks - especially when there is no reason at all for integration scholarship to be narrowly confined in the domain of traditional descriptive analyses and exegetic patterns of real-life events.

With this in mind, and from a rather optimistic interpretation of European polity dynamics, it is possible to suggest that a shift in paradigm has taken place since the mid-1990s, namely 'from policy to polity' or, somewhat differently, 
'from diplomacy to democracy'. This new transition stage is best captured by the term 'nascent Gemeinschaft'. Leaving aside for the moment the moderate reform packages agreed in Amsterdam and Nice, especially with reference to the process of democratising the Union, the post-Maastricht phase can be seen as part of a wider political evolution - even constitutional if one were to describe the formal treaty framework as the EU's 'political constitution' - towards a European 'public sphere', comprising citizens capable of being simultaneously conscious of their separate existence as distinct entities and of their collective existence as a composite demos. In particular, nascent Gemeinschaft aims at distancing current integration practices from the logic of consensus elite government by means of stressing the democratic potential of European citizens. Instead of large-scale decisions being the result of intensive interelite accommodation mostly through in camera bargaining, they should be subjected as closely as possible to the conditions of the democratic process, the most crucial of which refers to the notion of European 'civic competence': the institutional capacity of EU citizens to be actively involved in the governance of the larger polity. ${ }^{77}$ Nascent Gemeinschaft focuses on the process of turning an aggregate of electors into a politically responsible demos whose members feel part of a larger purposive whole and are capable of directing their democratic claims to, and via, the central institutions, thus opening the way towards a new democratic civitas in Europe.

In this sense also, nascent Gemeinschaft can be seen as both a conceptual position and a new point of departure for citizens to develop a more profound sense of civicness within an 'inclusive' European polity. Here, the term 'polity' refers to a system of governance capable of engaging its component state/citizen parts in the making of authoritative political decisions which have implications for the allocation of values in the transnational society. The characterisation of the Union as an 'emerging polity', compound yet easily identifiable as a collectivity, refers to no less. In fact, it is now possible to contemplate the idea of replacing the rather deterministic concept of 'integration', whose teleology is closely linked to the 'directionality' of the general system, with that of 'polityformation': the making of a large-scale political system composed of highly interdependent states and demoi, characterised by overlapping, intersecting and often competing policy arenas, public spheres and civic spaces. Although 'integration' remains useful in the vocabulary of EU studies, insofar as it purports to explain the joining together of previously autonomous units under a new regional centre, 'polity-formation' is better equipped to capturing the constitutive nature of European governance. In short, for a polity that is constantly under the scrutiny of international scholarship, but where no substantive consensus or even convergent conceptual understandings exist on its social and political ontology, the search for clear answers (and questions) is no easy task. Such problems, however, will be compounded even further should we fail to investigate the normative implications that polity-building generates for the future of Europe. 
Keeping these theoretical notes in mind, we can now move on to the politics of the IGC 1996/97, and the extent to which the resulting AMT represented a significant step towards furthering the democratic properties of the EU system, or whether it corresponded to a largely managerial type of reform designed to preserve the intrinsic nature of the Union as a confederal consociation, and with it the premium it places on consensus elite government and the practice of political co-determination. We will then examine, in Chapter 4 , the Nice process and outcome, following the conclusion of the IGC 2000 and the subsequent signing of the NIT in February 2001. In both case studies, our previous theoretical analysis will act as a wider laboratory of concepts and ideas so arranged as to help us throw some additional light on the dynamics of European governance since the late 1990s. It is to this demanding but no less exciting task that we now turn.

\section{Notes}

1 J. Tranholm-Mikkelsen, 'Neo-Functionalism: Obstinate or Obsolete? A Reappraisal in the Light of the New Dynamism of the EC', Millennium, Spring 1991, pp. 1-22.

2 See Robert O. Keohane and Stanley Hoffmann, 'Institutional Change in Europe in the 1980s', in Robert O. Keohane and Stanley Hoffmann (eds), The New European Community: Decisionmaking and Institutional Change, Boulder: Westview, 1991, pp. 1-39.

3 Paul Taylor, 'Prospects for the European Union', in Stelios Stavridis et al. (eds), New Challenges to the European Union: Policies and Policy-Making, Aldershot: Dartmouth, 1997, pp. 13-41.

4 Paul Taylor, International Organization in the Modern World: The Regional and the Global Process, London: Pinter, 1993, p. 99.

5 This formulation draws on Stephen D. Krasner, 'Structural Causes and Regime Consequences: Regimes as Intervening Variables', in Stephen D. Krasner (ed.), International Regimes, Ithaca: Cornell University Press, 1983, p. 2.

6 Simon Bulmer and Andrew Scott, 'Introduction', in Simon Bulmer and Andrew Scott (eds), Economic and Political Integration in Europe: Internal Dynamics and Global Context, Oxford: Basil Blackwell, 1994, p. 8. Cf. Stelios Stavridis, 'The "Second” Democratic Deficit in the European Community: The Process of European Political Co-operation', in F. R. Pfetsch (ed.), International Relations and Pan-Europe: Theoretical Approaches and Empirical Findings, Münster: Lit Verlag, 1993, pp. 173-94; and M. Anderson, M. den Boer and G. Miller, 'European Citizenship and Cooperation in Justice and Home Affairs', in Andrew Duff et al. (eds), Maastricht and Beyond: Building the European Union, London: Routledge, 1994, pp. 104-22.

7 Paul Demaret, 'The Treaty Framework', in D. O'Keeffe and P. M. Twomey (eds), Legal Issues of the Maastricht Treaty, London: Wiley Chancery Law, 1994, p. 6.

8 Roy Pryce, 'The Maastricht Treaty and the New Europe', in Duff et al. (eds), Maastricht and Beyond, p. 3.

9 Helen Wallace, 'European Governance in Turbulent Times', Journal of Common Market Studies, September 1993, p. 294.

10 George Ress, 'Democratic Decision-Making in the European Union and the Role of the European Parliament', in D. Curtin and T. Heukels (eds), Institutional Dynamics of European Integration: Essays in Honour of Henry G. Schermers, Vol. II, Dordrecht: Martinus Nijhoff, 1994, p. 156. 
11 Clive Archer, International Organisations, 2nd edn, London: Routledge, 1992, p. 37.

12 M. Forsyth, 'Towards a New Concept of Confederation', European Commission for Democracy Through Law, Council of Europe, 1994, p. 14.

13 For details see Stelios Stavridis, 'Democracy in Europe: West and East', in Conference Proceedings, People's Rights and European Structures, Manresa, September 1993, p. 130.

14 Karlheinz Neunreither, 'The Syndrome of Democratic Deficit in the European Community', in G. Parry (ed.), Politics in an Interdependent World: Essays Presented to Ghita Ionescu, Aldershot: Edward Elgar, 1994, p. 96.

15 Andrew Moravcsik, 'Preferences and Power in the European Community: A Liberal Intergovernmentalist Approach', Journal of Common Market Studies, December 1993, pp. 473-524. See also Robert D. Putnam, 'Diplomacy and Domestic Politics: The Logic of Two-level Games', International Organization, 42:3, 1988, pp. 427-60.

16 Ibid., p. 507. See also Ben Rosamond, Theories of European Integration, London: Palgrave, 2000, p. 143.

17 Ibid., p. 408.

18 Wolfgang Wessels, 'An Ever Closer Fusion? A Dynamic Macropolitical View on Integration Processes', Journal of Common Market Studies, June 1997, pp. 267-99.

19 Ibid., p. 273.

$20 \mathrm{Ibid}$. and p. 274. See also Alan S. Milward, The European Rescue of the Nation State, Berkeley, CA: California University Press, 1992.

21 Wessels, 'An Ever Closer Fusion?', p. 274.

22 Ibid., p. 287.

23 Simon Bulmer, 'The Governance of the European Union: A New Institutionalist Approach', Journal of Public Policy, 13:4, 1993, pp. 351-80.

24 Ibid., p. 353.

25 Ibid., p. 355.

26 Ibid.

27 Ibid., p. 370.

28 Gary Marks, Leisbet Hooghe and Kermit Blank, 'European Integration from the 1980s: State-centric v. Multi-level Governance', Journal of Common Market Studies, September 1996, pp. 341-78.

29 Ibid., p. 342.

30 Ibid., pp. 342-3.

31 Ibid., p. 372.

32 Ibid.

33 James Caporaso, 'The European Union and Forms of State: Westphalian, Regulatory or Post-Modern?', Journal of Common Market Studies, March 1996, pp. 29-52.

34 Ibid., p. 33.

35 Ibid.

36 Ibid., p. 29.

37 Ibid., pp. 35, 39, 45.

38 Philippe C. Schmitter, 'Some Alternative Futures for the European Polity and their Implications for European Public Policy', in Yves Mény et al. (eds), Adjusting to Europe: The Impact of the European Union on National Institutions and Policies, London and New York: Routledge, 1996, p. 25.

39 Ibid., p. 26.

40 Ibid., pp. 30-1.

41 Ibid., p. 31.

42 Ibid.

43 Ibid.

44 For further details see Dimitris N. Chryssochoou, 'Democracy and Symbiosis in the European Union: Towards a Confederal Consociation?', West European Politics, October 1994, pp. 1-14. 
45 Arend Lijphart, 'Consociation and Federation: Conceptual and Empirical Links', Canadian Journal of Political Science, September 1979, p. 506.

46 Paul Taylor, 'The Politics of the European Communities: The Confederal Phase', World Politics, April 1975, p. 346.

47 This has been described elsewhere as an 'inverse pyramid'. For further details see Michael J. Tsinisizelis and Dimitris N. Chryssochoou, "From "Gesellschaft" to "Gemeinschaft"? Confederal Consociation and Democracy in the European Union', Current Politics and Economics of Europe, 5:4, 1995, pp. 1-33.

48 Taylor, 'The Politics of the European Communities', p. 336.

49 Dimitris N. Chryssochoou, 'European Union and the Dynamics of Confederal Consociation: Problems and Prospects for a Democratic Future', Journal of European Integration, 18:2-3, Winter/Spring 1996, pp. 279-305.

50 See Dimitris N. Chryssochoou, “Europe's Could-be Demos": Recasting the Debate, West European Politics, October 1996, pp. 787-801. Cf. Dimitris N. Chryssochoou, 'Rethinking Democracy in the European Union: The Case for a "Transnational Demos", in Stavridis et al. (eds), New Challenges, pp. 67-85.

51 Thomas Christiansen, Knud E. Jørgensen and Antje Wiener, 'The Social Construction of Europe', Journal of European Public Policy, 6:4, 1999, pp. 528-9.

52 Ibid., p. 529.

53 Quoted in Ibid. For the original argument see J. G. Ruggie, Constructing the World Polity: Essays on International Institutionalization, New York: Routledge, 1998, p. 33.

54 Jo Shaw and Antje Wiener, 'The Paradox of the "European Polity"', in M. Green Cowles and Michael Smith (eds), State of the European Union, Volume 5: Risks, Reform, Resistance, and Revival, Oxford: Oxford University Press, 2000, pp. 67-8.

55 Ibid., pp. 75, 87.

56 Christiansen et al., 'The Social Construction of Europe', p. 537.

57 Ibid., p. 538.

58 Ibid., p. 543.

59 Shaw and Wiener, 'The Paradox', p. 68.

60 Richard Bellamy and Dario Castiglione, 'Democracy, Sovereignty and the Constitution of the European Union: The Republican Alternative to Liberalism', in Z. Bañkowski and A. Scott (eds), The European Union and its Order London: Blackwell, 2000, p. 181.

61 Ibid., p. 182.

62 Ibid., p. 181.

63 See Neil MacCormick, 'Democracy, Subsidiarity, and Citizenship in the "European Commonwealth"', Law and Philosophy, 16, 1997, pp. 331-56.

64 Richard Bellamy and Dario Castiglione, 'Building the Union: The Nature of Sovereignty in the Political Architecture of Europe', Law and Philosophy, 16:4, 1997, p. 443.

65 MacCormick, 'Democracy', p. 338.

66 See Leon N. Lindberg and Stuart A. Scheingold, Europe's Would-Be Polity: Patterns of Change in the European Community, Englewood Cliffs, NJ: Prentice-Hall, 1970.

67 Ernst B. Haas, 'The Study of Regional Integration: Reflections on the Joy and Anguish of Pretheorising', International Organization, 24:4, 1970, p. 635.

68 Sidney Tarrow, 'Building a Composite Polity: Popular Contention in the European Union', Institute for European Studies Working Paper, No. 98/3, Cornell University, 1998, p. 1.

69 Wayne te Brake, Shaping History: Ordinary People in European Politics, 1500-1700, Berkeley and Los Angeles: University of California Press, 1998, p. 278.

70 Paul P. Craig, 'Democracy and Rule-making within the EC: An Empirical and Normative Assessment', European Law Journal, 3:2, 1997, p. 114.

71 Ibid., p. 115.

72 Ibid., p. 116.

73 Kostas A. Lavdas, 'Republican Europe and Multicultural Citizenship', Politics, 21:1, 2001, 
pp. 1-10. See also Philip Pettit, Republicanism: A Theory of Freedom and Government, Oxford: Clarendon Press, 1997.

74 Ibid., p. 4.

75 Ibid., p. 5.

76 Ibid., p. 6.

77 See Dimitris N. Chryssochoou, 'Metatheory and the Study of the European Union: Capturing the Normative Turn', Journal of European Integration. 22:2, 2000, pp. 123-44. 